\title{
The pupa of Calamoceras marsupus Brauer, 1865 (Trichoptera: Calamoceratidae)
}

\author{
H. Tachet ${ }^{1 *}$, M.A. González² \\ 1 UMR CNRS-5023, Ecologie des Hydrosystèmes Fluviaux, 43 Bd. 11 novembre 1918, F-69622 Villeurbanne cedex, France. \\ 2 Departamento de Biología Animal, Facultad de Biología, Universidad de Santiago de Compostela, E - 15782 Santiago de Compostela (A \\ Coruña), Spain.
}

\begin{abstract}
The pupa of Calamoceras marsupus Brauer, 1865 (Trichoptera : Calamoceratidae) is described and the main taxonomic characteristics are illustrated. This pupa is compared with those of six genera of Calamoceratidae. The pupa of Calamoceras marsupus shares some characteristics with Banyallarga, Phylloicus, and Ganonema.
\end{abstract}

Keywords : Trichoptera, pupae, Calamoceras, Calamoceratidae.

\section{Introduction}

The genus Calamoceras is the only representative of the family Calamoceratidae in the Western Palearctic Region. There are only two species : Calamoceras marsupus Brauer, 1865 which occurs in the Iberian Peninsula and in France, and C. illiesi Kumanski \& Malicky, 1974 which occurs in the Balkan Peninsula. In Europe, most Trichoptera pupae were described, generally at the family level, at the beginning of the twentieth century (Thienemann 1905, Ulmer 1909). However, about fifty years later, the pupa of Calamoceras marsupus still remained unknown (Bertrand 1955). Coineau \& Jacquemart (1963) gave a first description of the pupa of Calamoceras marsupus (as C. volxemi), but this description is too brief to make relevant comparisons with the descriptions of other pupae of European Trichoptera. Thus, we present, in this publication, a more complete description of the pupa of Calamoceras marsupus Brauer, 1865. Moreover, we will compare the pupa of this genus with that of other genera of Calamoceratidae.

\footnotetext{
* Corresponding author :

E-mail : h.tachet@wanadoo.fr
}

\section{Material examined}

The material examined was exuviae resulting from the laboraratory rearing of one pupa collected in the Tella River, Pite (La Coruña, Spain). The adult which emerged on 25 April 1994 was a male of Calamoceras marsupus. This rearing, in laboratory conditions, gave exuviae that were perfectly clear and in good condition.

\section{Description}

Length : $12 \mathrm{~mm}$; width : $3 \mathrm{~mm}$.

Head - Labrum small, rounded, bearing 3 long setae at each posterolateral corner, two patches of long bristles present on 1/3 anterior of labrum; these bristles are not hooked apically (fig. 1a). Mandibles twice as long as basal width, curved slightly mesad, inner margin finely serrate, with two setae on rounded lateral margin near base (fig. 1b). Antennae reaching only posterior margin of abdominal segment VII.

Thorax - Pro- and mesothoracic tarsi bearing welldeveloped swimming fringes.

Abdomen - The abdomen (Fig. 2a) with dense lateral fringes of hairs from anterior end of segment III to posterior ventral margin of segment VIII, where the lateral

Article available at http://www.limnology-journal.org or http://dx.doi.org/10.1051/limn/2005018 


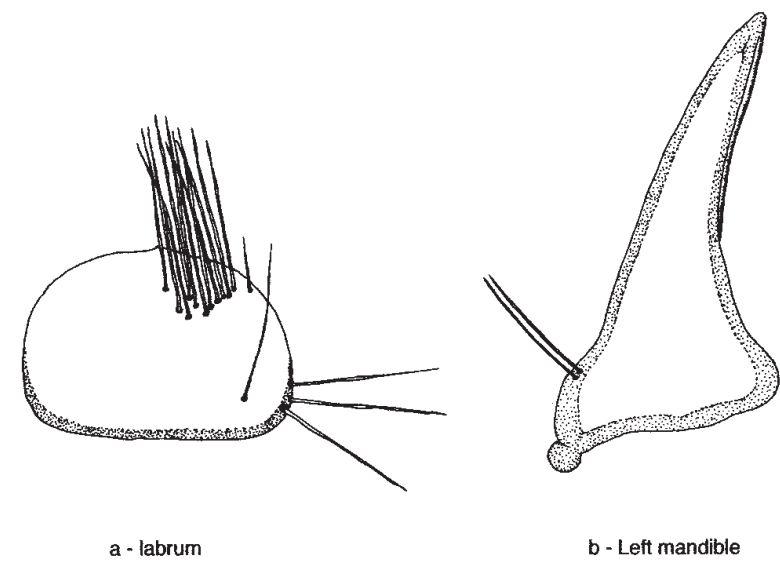

Fig. 1. Calamoceras marsupus. a - Pupal labrum dorsal view. The setae of the left part have been omitted. b - Pupal left mandible, dorsal view.

fringes are connected. Dorsally, abdominal segment I bearing two small ovoid posterior sclerites with numerous small hooks anteriorly directed. Hook plates present anteriorly on segment III-VII ; segment V with both anterior and posterior hook plates. Hook plates on segments III - VII lengthened transversally, with each bearing from 5 to 9 small hooks, this number of hooks varying slightly between the left and right sides. Fringe of hairs present on posterior margin of each dorsal abdominal segment II - VI, with only two clusters of setae on posterior margin of abdominal segment VII. Last abdominal segment sclerotized with four pointed processes dorsally, posterolateral processes triangular and sharply pointed, median processes upright, each ending in sharp point directed posterad. Ventrally two strong pointed processes (corresponding to anal rods) directed caudad (Figs. 2b-c).

Longitudinal sclerotized curved rods present dorsolaterally on abdominal segments I -VIII. Gills present dorsally, dorsolaterally, and ventrally from abdominal segment II to VI (dorsally), II to VII (ventrally). Anteriorly each pair of gills is 4-branched, only 3-branched on abdominal segment VII (Fig. 2a).

\section{Comparison with other Calamoceratidae pupae}

There are two subfamilies in the Calamoceratidae : Anisocentropinae and Calamoceratinae. The Anisocentropinae have only one genus Anisocentropus which occurs in five Regions (Table 1). The Calamoceratinae include 7 genera occurring in five Regions (Table
1). Until now, the pupae of six genera have been described : Anisocentropus (Ulmer 1955, Marlier 1962, Wallace \& Sherberger 1970), Heteroplectron (Llyod 1915, 1921 ; Patterson 1978), Ganonema (Ulmer 1955), Phylloicus (Flint 1964, Botosaneanu \& Sykora 1973, Bowles \& Flint 1997), Banyallarga (Flint \& Angrisano 1985), and Calamoceras (Coineau \& Jacquemart 1963 and the present description). Before presenting this comparison between these six genera, we need to clarify contradictory observations between Ulmer (1955) and Wallace \& Sherberger (1970) about the pupa of Anisocentropus.

In the key to the genera of Calamoceratidae pupae of Trichoptera, Ulmer (1955, page 415) indicated : “... vor dem Hinterrande der Tergite, besonders V bis VII, eine dichte Reihe von Haarborsten...". By implication this characteristic concerns the following genera : Anisocentropus, Ganonema, Heteroplectron, and Phylloicus. On the other hand, Wallace \& Sherberger (1970) indicated : "The pupa of $A$. pyraloides can be readily distinguished from that of Heteroplectron ("Ganone$m a$ ") by the absence of transverse hair patches on the dorsum of the abdomen on Anisocentropus ...". The drawings of Ulmer for Anisocentropus, are precise, but concern only details of the abdomen. Moreover, his written descriptions of the pupa of Anisocentropus concerning the abdomen were not explicit concerning the absence or the presence of transverse hair patches on the tergites of the abdomen. In order to clear up this problem, thanks to the help of Dr. Oliver S. Flint, jr, we have made direct observations of pupae of Anisocentropus pyraloides (Walker, 1852) (Fig. 3). The two pu-

Table 1. Distribution of the genera of Calamoceratidae in the World Biogeographic Regions [data from the Trichoptera World Checklist (Morse, 1999)]. AT : Afrotropical, AU : Australasian, EP : East Palearctic, NA : Nearctic, NT : Neotropical, OL : Oriental, WP : West Palearctic.

\begin{tabular}{|c|c|c|c|c|c|c|c|}
\hline \multirow[b]{2}{*}{ genera } & \multicolumn{7}{|c|}{ Biogeographic regions } \\
\hline & NT & NA & AT & WP & EP & $\mathrm{OL}$ & $A U$ \\
\hline Anisocentropus & & $\mathrm{X}$ & $X$ & & $X$ & $X$ & $X$ \\
\hline Ascalaphomerus & & & & & $\mathrm{X}$ & & \\
\hline Banyallarga & $x$ & & & & & & \\
\hline Calamoceras & & & & $X$ & & & \\
\hline Ganonema & & & & & $\mathrm{X}$ & $\mathrm{X}$ & \\
\hline Georgium & & & & & $\mathrm{X}$ & & \\
\hline Heteroplectron & & $x$ & & & $x$ & & \\
\hline Phylloicus & $\mathrm{X}$ & $\mathrm{X}$ & & & & & \\
\hline
\end{tabular}



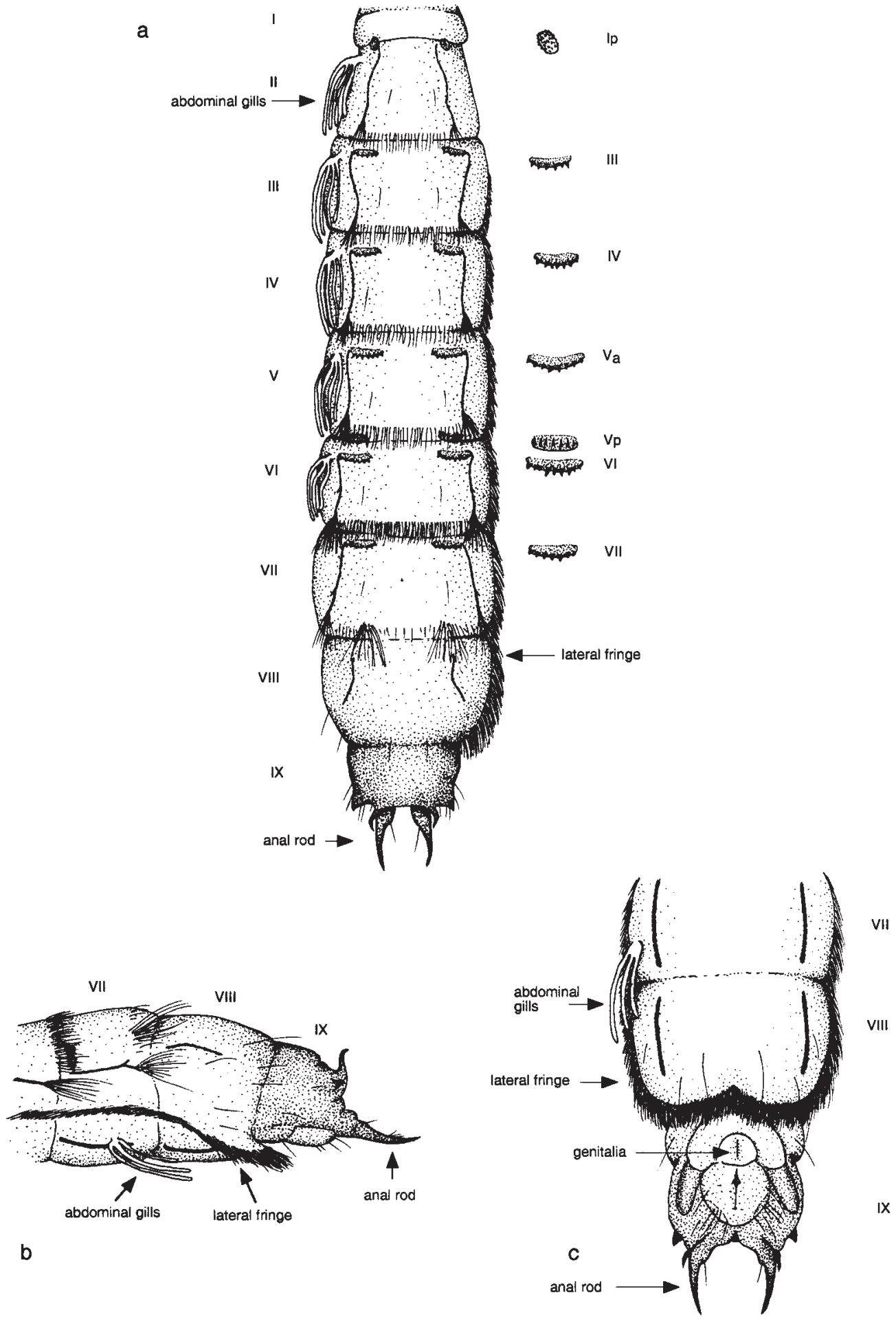

Fig. 2. Calamoceras marsupus. a. Pupal abdomen, dorsal view. (I-IX = segment number). Only the left gills are shown, and only the right lateral fringe is drawn. On the right, detail of hook plates (I- VII $=$ segment number; $\mathrm{a}=$ anterior, $\mathrm{p}=$ posterior). b. Pupal apex of abdomen, left lateral view. c. Apex of abdomen, ventral view, (The left gill of abdominal segment VII is omitted). 


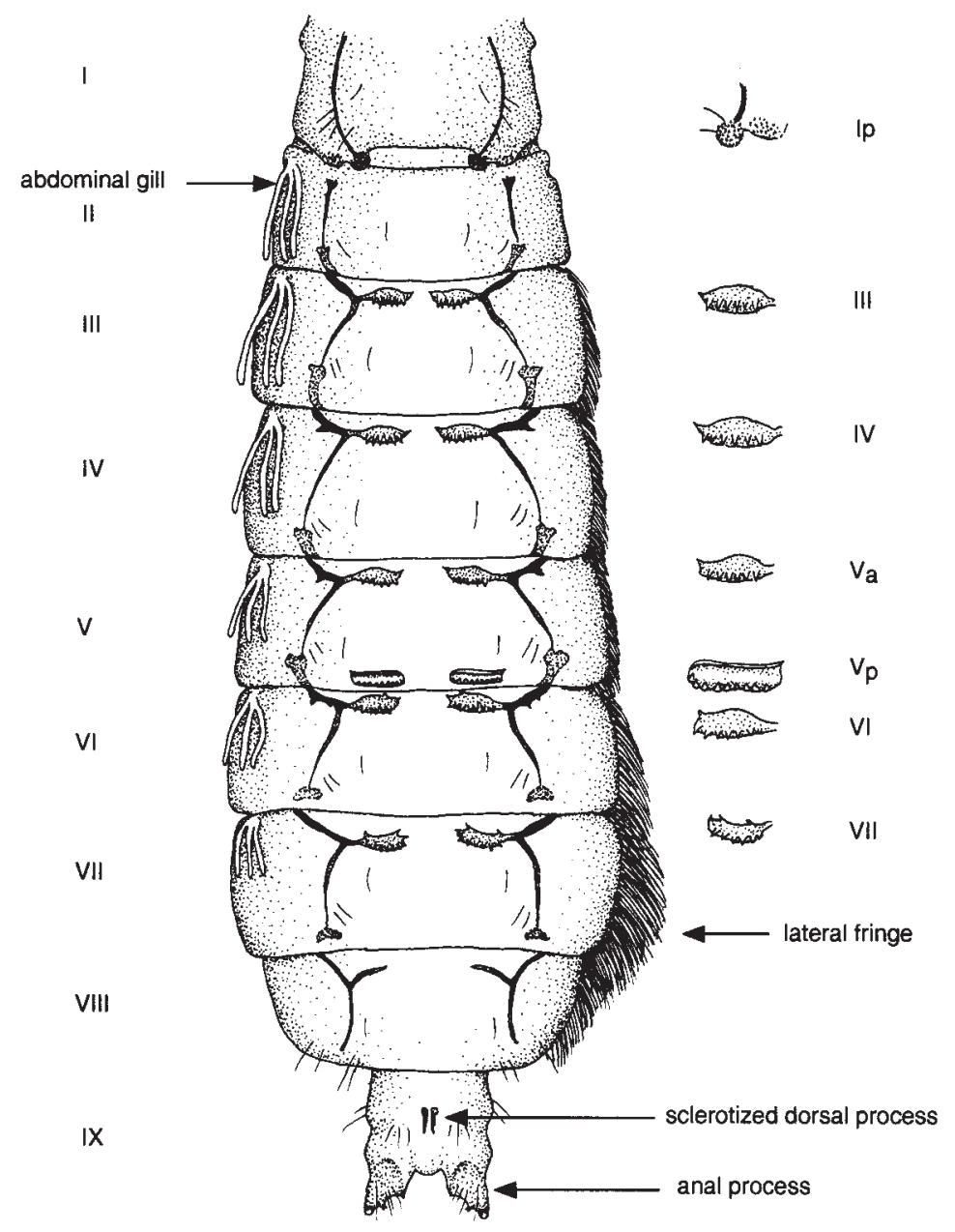

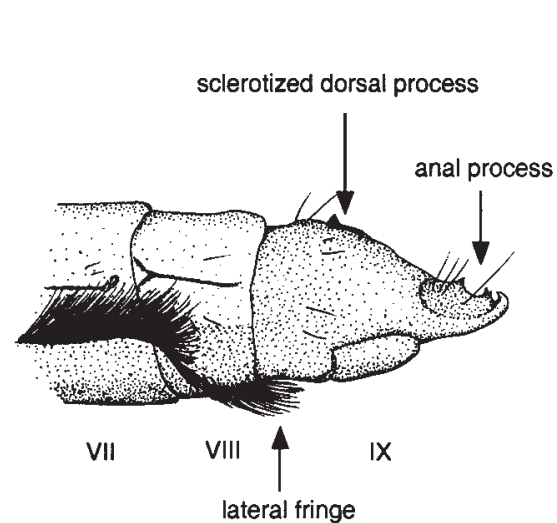

b

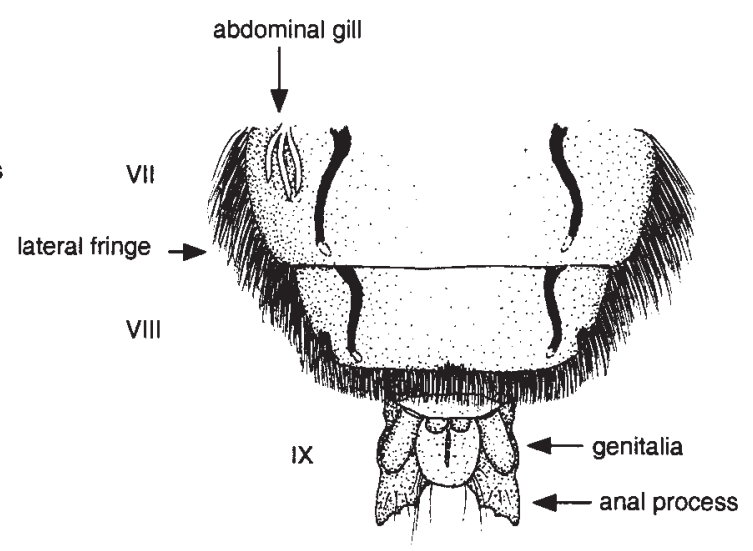

Fig. 3. Anisocentropus pyraloides. a. Pupal abdomen, dorsal view. (I-IX = segment number). Only the left gills are shown, and only the right lateral fringe is drawn. On the right, detail of hook plates (I- VII $=$ segment number; $a=$ anterior, $p=$ posterior). $b$. Pupal apex of abdomen, lateral view (The gills of abdominal segment VII are omitted). c. Apex of abdomen, ventral view (The left gill of abdominal segment VII is omitted). 

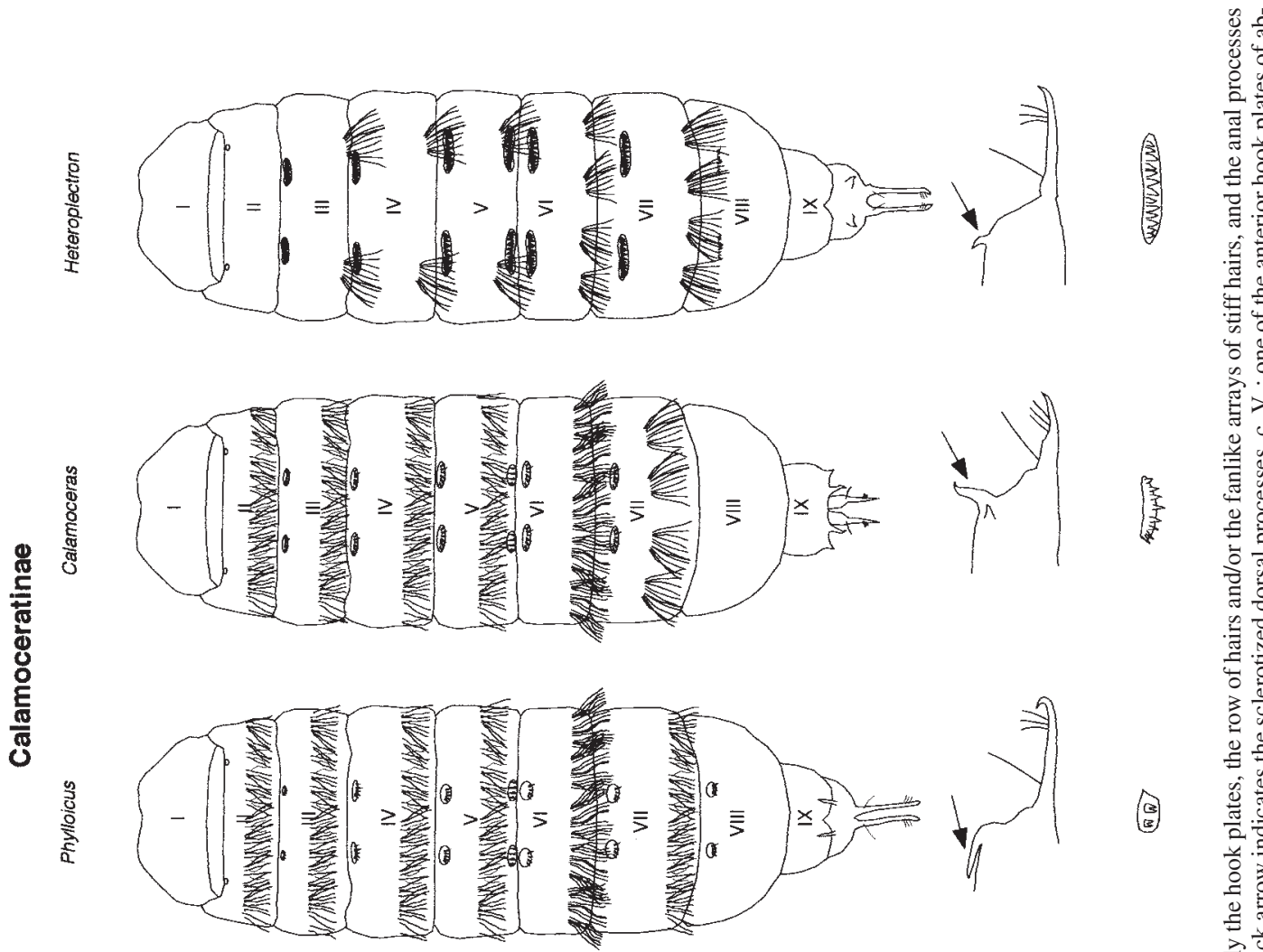

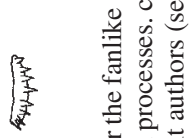

no

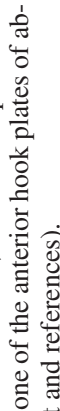

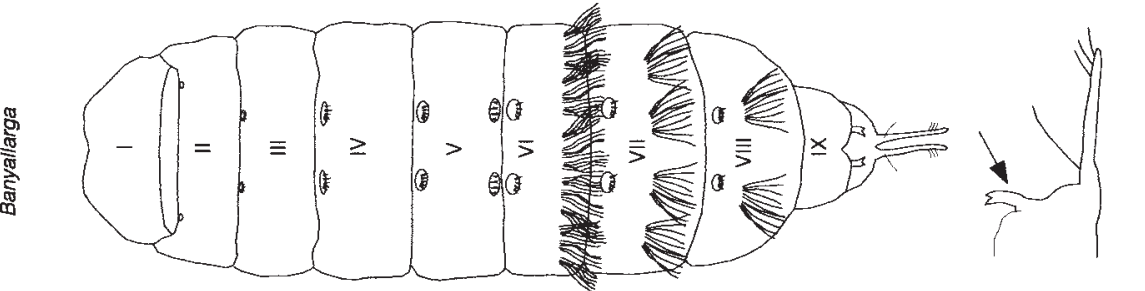

Ð

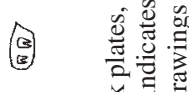

을

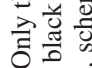

跤

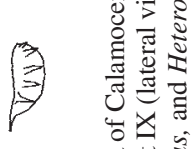

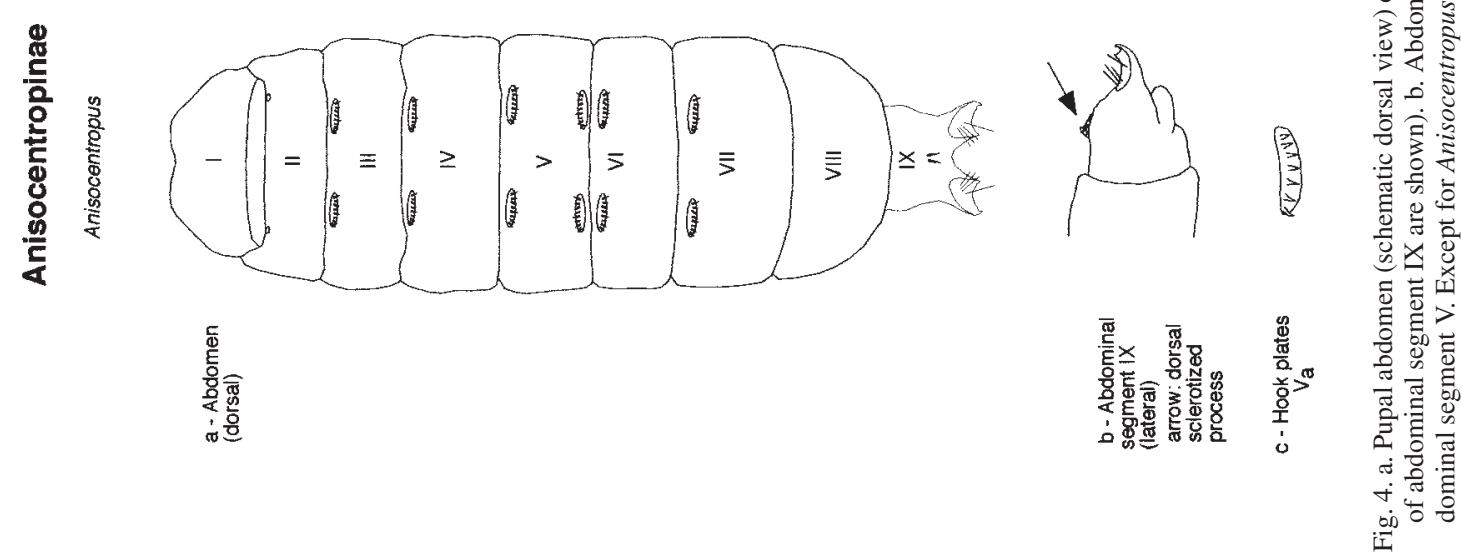


pae examined (one male and one female) correspond to pupal exuviae.

Head - At least in the males, the antennae are clearly shorter than the body in Calamoceras, clearly longer in Anisocentropus, Ganonema and Heteroplectron. There is no indication concerning the length of antennae for the other two genera. The labrum bears two tufts of long setae in Calamoceras and Anisocentropus, a single rank of long setae in Phylloicus and $\mathrm{Ga}$ nonema. The mandibles are very similar in the six genera.

Thorax - In Anisocentropus and Banyallarga only the tarsus of the mesothoracic legs bear fringes of hairs. In Ganonema and in Calamoceras the tarsus of the pro- and mesothoracic legs bears fringes of hairs. There is no indication concerning the presence of fringes of hairs on the prothoracic legs for the other two genera.

Abdomen (Fig. 4) - The abdomen is flattened in Anisocentropus (Fig. 3), more or less cylindrical in the other five genera. The disposition and the structure of gills are essentially the same as in the larva (see García de Jalón et al. 1982) for larva of Calamoceras marsupus), gills present dorsally, dorsolaterally, and ventrally from abdominal segment II to VI (dorsally), II to VII (ventrally). Anteriorly each pair of gills is 4-branched, only 3-branched on abdominal segment VII. In Heteroplectron there is one filament per gill cluster, three to four per gill cluster in the other genera. Dorsally, the abdomen bears a row of long hairs along the posterior margin of segments II to VII in Phylloicus, and Calamoceras, the row of hairs on segment VI is denser than on the other segments ; in Banyallarga there is only a dense row of hairs on segment VI and two pairs of fanlike arrays of stiff hairs on VII, only one pair on VIII. In Calamoceras there are two pairs of fanlike arrays of stiff hairs on VII. In Heteroplectron there are only fanlike arrays of stiff hairs on segment III to VII (one pair on segment III to V, two pairs on segments VI and VII). Confirming the observations of Wallace \& Sherberger (1970), there is no row of long hairs along the posterior margin of segments II to VII in Anisocentropus (Figs. 3-4). The arrangement of the lateral fringe is the same in the six genera.

In the six genera, abdominal tergum I bears a pair of ovoid posterior sclerites with small anteriorly directed points. Anterior hook plates occur on abdominal terga III to VIII in Phylloicus, Banyallarga, and Heteroplectron, but only on terga III to VII in Anisocentropus, Ganonema, and Calamoceras. These hook plates are broadened transversally in Heteroplectron, Ganonema and Calamoceras, only slightly broader than long in Banyallarga and Phylloicus. In Anisocentropus pyraloides where the hook plates are broadened transversally, the right series is more elongated than the left series according to Wallace \& Sherberger (1970), but we have not observed this asymmetry in the two pupae that we examined (Fig. 3).

The anal rods are long and slender, each with a long subbasal seta and 3 subapical ones in Banyallarga, Phylloicus, Ganonema, and Heteroplectron. Dorsally, in these four genera, a pair of sclerotized processes (corresponding to the Halteapparat der Fühler according to Ulmer 1955) occurs on segment IX. In Calamoceras the anal rods also bear a long subbasal seta, and 3 subapical ones, but they are sclerotized and pointed ; dorsally there are two pairs of pointed processes probably corresponding to sclerotized dorsal processes of the other genera.

In Anisocentropus, the anal processes are broad, short and bilobed (Figs. 3-4). Each lobe forms dorsally a small depression extending in two (or three) short curved points. A pair of sclerotized dorsal processes is present (Figs. 3-4).

\section{Conclusions}

The five pupae of Calamoceratinae display a common character in the row of long hairs and/or fanlike arrays of stiff hairs along the posterior margin of abdominal segments. The pupa of Calamoceras presents many common characteristics with Phylloicus and $\mathrm{Ba}$ nyallarga, but the apex of the abdomen is more sclerotized than in these two genera. Moreover the hook plates are elongated transversally in Calamoceras. The pupa of Heteroplectron is different from the other five.

The apex of the abdomen of the pupa of Anisocentropus is very different from that of the pupae of Calamoceratinae and resembles that of Phryganeidae pupae. There is no row of long hairs and/or fanlike arrays of stiff hairs along the posterior margin of abdominal segments in Anisocentropus, but there is a pair of sclerotized dorsal processes on abdominal segment IX.

Finally, Anisocentropinae and Calamoceratinae pupae share only one characteristic : the presence of a pair of sclerotized dorsal processes on abdominal segment IX.

\footnotetext{
Acknowledgements

We thank Rufino Vieira (University of Santiago de Compostela) for providing us with pupae of Calamoceras marsupus for exami-
} nation. We should like to thank Leah A. Bêche (University of 
Berkeley, California) for providing us with pupae of Heteroplectron californicum for examination. We should like to thank Oliver S. Flint, Jr. (Smithsonian Institution, Washington DC) for providing us with pupae of Anisocentropus pyraloides and a pupa of Anisocentropus sp. from Sri Lanka for examination. We should also like to thank Leah A. Bêche, and also John C. Morse (University of Clemson, South Carolina), Aysha Prather (University of Memphis, Tennessee), Oliver S. Flint Jr. (Smithsonian Institution, Washington DC), Robert W. Wisseman (Corvallis, Oregon) for their remarks and their help in obtaining out-of-print publications. Financial and technical support for this contribution was provided by the Xunta de Galicia (PGIDIT04PXIB20002PR) and the "Estación de Hidrobioloxía Encoro do Con" (University of Santiago de Compostela). We thank two anonymous referees for helpful comments on the manuscript.

\section{References}

Bertrand H. 1955. - Les insectes aquatiques d'Europe. Vol 2, P. Lechevalier, Paris, $547 \mathrm{p}$.

Botosaneanu L. \& Sykora J. 1973. - Résultats des expéditions biospéologiques cubano-roumaines à Cuba. Editura Academiei Republicii Socialiste Romania, Bucuresti, 379 - 407.

Bowles D. E. \& Flint Jr. O. S. 1997. - The genus Phylloicus (Trichoptera : Calamoceratidae) in the United States, with a redescription of Phylloicus ornatus (Banks). Pages 53-58 in Holzenthal R. W. \& Flint O. S. (eds) : Proc. $8^{\text {th }}$ Int. Symposium on Trichopte$r a$, Minneapolis 1995, Ohio Biol. Survey, Columbus, Ohio, XIII + $496 \mathrm{p}$.

Coineau Y. \& Jacquemart S. 1963. - Missions S. Jacquemart dans les Pyrénées Orientales $\left(4^{\circ}\right.$ note. A propos de quelques Trichoptères des Pyrénées Orientales). Bull. Inst. R. Sc. Nat. Belg., 39 , 1-40.

Flint Jr. O. S. 1964. - The Caddisflies (Trichoptera) of Puerto Rico.
University of Puerto Rico. Agric. Exper. Station Techn. Paper, 40, $1-80$

Flint Jr. O. S. \& Angrisano E. B. 1985. - Studies of Neotropical caddisflies XXXV : the immature stages of Banyallarga argentinica Flint (Trichoptera : Calamoceratidae). Proc. Biol. Soc. Wash., 98, 687-697.

García de Jalón D., Cortes R. M. V. \& Knoben R. 1987. - The larva of Calamoceras marsupus Brauer, 1865. Arch. Hydrobiol., 110 (4), 617-622.

Lloyd J. T. 1915. - Wood-boring Trichoptera. Psyche, 22, 17-21.

Lloyd J. T. 1921. - The biology of North American caddis fly larvae. Bulletin of the Lloyd Library of Botany, Pharmacy and Materia Medica, 21, Entomological Series 1, pages 87-92 (124 p). Cincinnati, Ohio.

Marlier G. 1962. - Genera des Trichoptères de l'Afrique. Musée Royal de l'Afrique Centrale. Tervuren, Belgique. Annales, série in 8, Sciences zoologiques, $\mathrm{N}^{\circ} 109,261 \mathrm{p}$.

Morse J. C. 1999. - Trichoptera World Checklist. Available from : http://entweb.clemson.edu/database/trichopt/index.htm

Patterson J. W. 1978. - The life history of Heteroplectron americanum (Walker) (Trichoptera : Calamoceratidae). M.S. Thesis, University of Delaware, $52 \mathrm{p}$

Thienemann A. 1905. - Biologie der Trichopteren-Puppe. Zoologischen Jahrbüchern, Bd. 22, Abt.f.Systematik, Ed. G. Fischer, Iena, $86 \mathrm{p}$.

Ulmer G. 1909. - Trichoptera in "Brauer, Die Süsswasserfauna Deutschlands", G. Fischer, Iena, 5/6, 326 p.

Ulmer G. 1955. - Köcherfliegen (Trichopteren) von den Sunda-Inseln. Arch. f. Hydrobiol. / Suppl., XXI, 3/4, 408-608.

Wallace J. B. \& Sherberger F. F. 1970. - The immature stages of Anisocentropus pyraloides (Trichoptera : Calamoceratidae). J. Georgia Entomol. Soc. 5, 217-224. 